\title{
EDITORIAL
}

\section{A future of island studies}

\author{
Adam Grydehфj \\ Ilisimatusarfik/University of Greenland, Nuuk, Greenland \\ Institute of Island Studies, University of Prince Edward Island, Charlottetown, Canada \\ Island Dynamics, Copenhagen, Denmark \\ agrydehoj@islanddynamics.org
}

\begin{abstract}
Island studies has developed into an established, interdisciplinary research field. It is important that island studies not only continue deepening its internal theoretical understandings but also reach out to other fields and regions that have received limited attention within island studies. It is also necessary for island studies to grapple with a number of problematic tendencies within the field and the wider scholarship, including by challenging the misuse of island spatiality to produce idealised visions of islands (for example in island sustainability research). Similarly, it is important to pursue a decolonial island studies that rethinks the ways in which island development research can end up marginalising Indigenous voices at the same time as it seeks to understand islands 'on their own terms'.
\end{abstract}

Keywords: decolonial, interdisciplinary research, island development, island studies, sustainability https://doi.org/10.24043/isj.1

(C) 2017 - Institute of Island Studies, University of Prince Edward Island, Canada.

Island studies, many say, is an emerging field.

We live in an age that valorises dynamism and change, so it flatters our sensibilities to participate in a scholarly project that is not fixed, fusty, or static. If island studies is emerging, then we who contribute to it are at the vanguard, engaging in a new way of doing research.

But this mantra of 'emergence', 'burgeoning', 'growth', 'institutionalisation' is also an apology-repeated across a range of important literature reviews and theoretical texts (e.g., Baldacchino, 2004; Baldacchino, 2006; Shima Editorial Board, 2007; Fletcher, 2011; Brinklow, 2011; Mountz, 2015; Swaminathan, 2015; Pugh, 2016b; Rankin, 2016). It is a sheepish admission that 'Yes, we're aware that you've never heard of island studies and that you may find the very idea ridiculous. But we're working on it.' It is a vain hope that, by labelling the field a work in progress, we may pre-empt criticism, save some face, appear more substantial than the islands we study-the islands that we, chronically protesting too much, insist are disproportionately significant, bellwethers, models of innovation, misrepresented, and misunderstood. If island studies is still emerging, then there may yet be hope for islands themselves.

Such apologies are tempting. I myself have apologised for the field in this manner. When it comes to talking down island studies, I have learned from the best.

Yet this apology is ineffective, and even if it were effective, to persist in it today would be intellectually dishonest. Island studies has come too far. It is imperfect. It is flawed. But it is here. 
Figure 1: Dinghai Harbour, Zhoushan Archipelago, China.

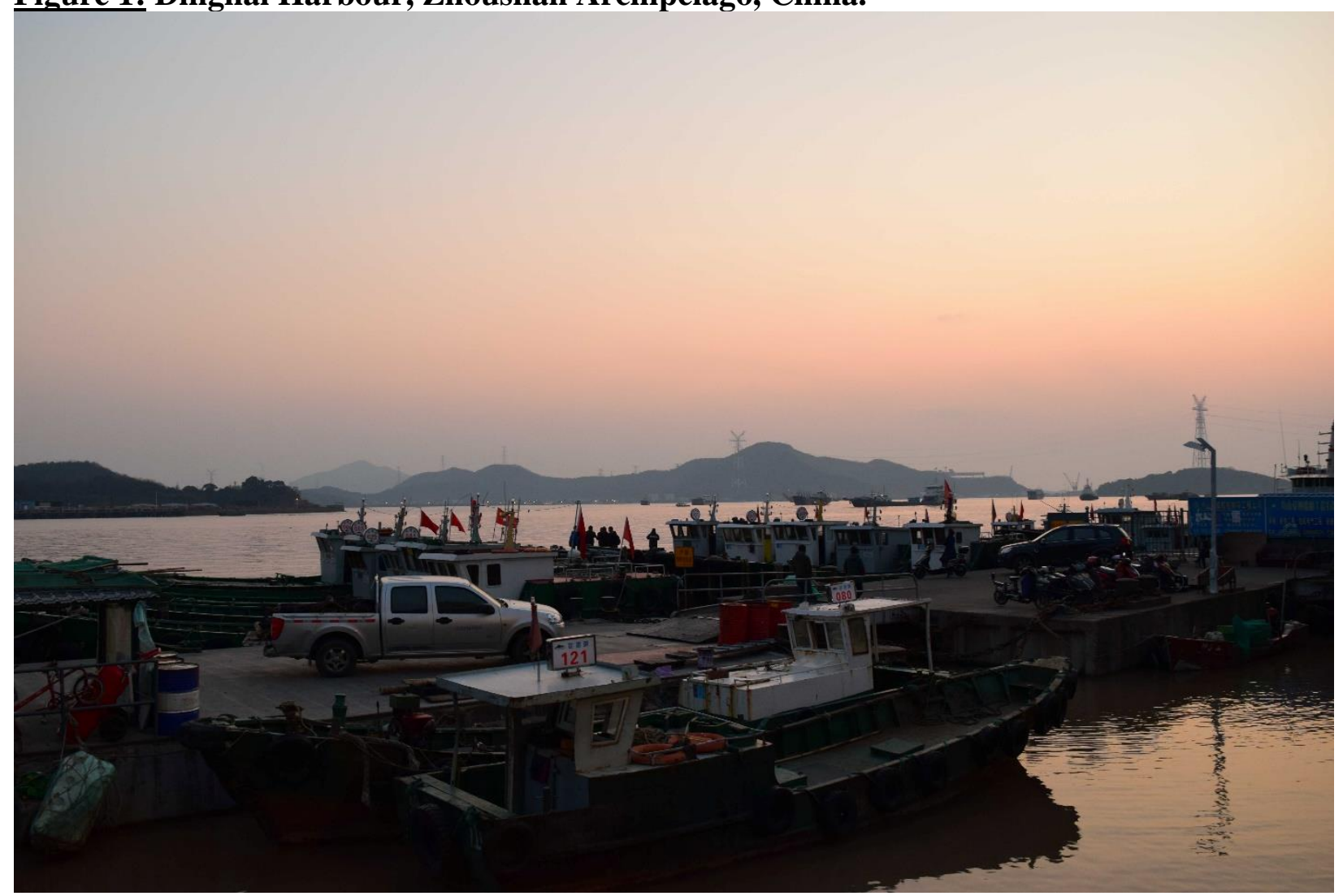

Source: Adam Grydehøj, 2017.

\section{Beginnings}

Island studies has undergone a long process of field construction. 1988 was a 'watershed' for island studies (Baldacchino, 2015, p. 4), in part because that year saw the coming together of a group of researchers who in 1992 would establish the International Small Island Studies Association (ISISA). Already in 1991, Russell King (2015) drew up initial proposals for a journal to be published by the University of Prince Edward Island's Institute of Island Studies. As it happened, this task would eventually fall to Godfrey Baldacchino, who in 2003 began the practical groundwork for Island Studies Journal (ISJ), the first issue of which appeared in May 2006. In his editorial introduction to ISJ's inaugural issue, Baldacchino (2006, p. 8) expresses the need for "a suitable branded journal of island studies," without which the field would likely "remain a loose and uncoordinated collection of research initiatives in search of a 'home'."

Baldacchino served as ISJ's executive editor from the journal's founding all the way up until November 2016, when he handed the reins over to me. His hope that ISJ could address "the urgency to develop and nurture an audience for island studies scholarship and a reputable platform for a growing community engrossed by island studies" (Baldacchino, 2006, p. 10) has been well and truly met, in no small part because of his own tireless efforts to establish the field. ISJ has become not only a model for the liberatory potential of open-access, peer-reviewed academic publishing but also a respected publication in its own right. ISJ is now listed in Scopus, the Web of Science's Social Science Citation Index, and the Directory of Open Access Journals (DOAJ). 
Between May 2006 and November 2016, ISJ published 193 research papers and review essays. These articles have taken a wide range of disciplinary and regional perspectives-though with some disciplinary, topical, and geographical strengths and weaknesses (Stratford, 2015). I am proud to call Baldacchino my mentor and humbled to succeed him as executive editor of ISJ, having the opportunity to build upon his groundbreaking work. If Baldacchino's task as executive editor was to usher island studies through its period of emergence, mine is to manage its establishment. A less romantic task, perhaps, but one that involves its own intellectual challenges.

\section{Grounding-and watering-island studies}

The study of islands has a long history (Baldacchino, 2006, pp. 6-7), yet we can differentiate between early studies of individual islands and particular aspects of insularity on the one hand and the movement from the 1980s on toward a more general study of islands and island societies per se.

Instead of attempting a complete or even cursory history of island studies, I will sketch out a single strand in the field's development, not to raise it above the others but as a means of illustrating some reasons why the field is so complex. The ideal image of the island-a neatly bounded piece of land, surrounded by water-is engaging in its straightforward conceivability. Yet the contrast between this alluring conceptual simplicity and the complexity of island life itself has resulted in a scholarly field that cannot escape certain submerged contradictions and hazy paradoxes. Fruitfully intractable theoretical problems belie the field's surface-level clarity of purpose.

One strand of what would develop into today's interdisciplinary field of island studies originated in a pushback against certain development-oriented forms of Pacific studies, with Epeli Hau'ofa's evocation of "a sea of islands" (Hau'ofa, 1994) feeding into Grant McCall's vision of 'nissology', "the study of islands on their own terms" (McCall, 1994, p. 2). Several regional island studies emerged roughly simultaneously as critical responses to various problematic island discourses, resulting in distinctive Caribbean and Indian Ocean island studies, among others. Owe Ronström (2013, p. 154) has more recently discussed this kind of scholarly process as the difference between studying islands as locus and islands as focus, "the relations between the discourses about islands and islands as physical spaces, between islands as metaphors (or models) and as lived realities."

The coalescing of regional island studies into a wider scholarly community was strengthened by Baldacchino's efforts to conceptualise an interdisciplinary island studies (e.g., Baldacchino, 2004; 2006; 2008), which broadened out beyond his earlier and continuing research interest in small island political innovation (e.g., Baldacchino \& Milne, 2000; Baldacchino \& Milne, 2009; Baldacchino, 2010b; Hepburn \& Baldacchino, 2016), entrepreneurship (e.g., Baldacchino, 1999; 2002; 2010a), and other issues. Baldacchino sought a third way between development-oriented, vulnerability-focused island research on the one hand and radical localisation of research perspectives on the other by refocusing on the island itself. That is, whereas a portion of the previous generation of island research had sought to overcome marginalising representations of insularity but in so doing risked losing sight of the island, Baldacchino (2004, p. 274) called for a study of islandness as a state of tension between "openness and closure." Islands, Baldacchino (2004, p. 278) argued, are more than simply microcosmic research laboratories for mainlanders or worlds-unto-themselves for islanders; instead, "islandness is an intervening variable that does not determine, but contours and conditions physical and social events in distinct, and distinctly relevant, ways."

In his pitch for island studies, Baldacchino shows that it is precisely because of the undeniable psychological appeal and simplicity of islandness that we must face up to consequences of this 'island allure', rather than rail against the injustice of it. To criticise, for example, the use 
of islands as laboratories by researchers and policy-makers is not to deny that islands have special characteristics that encourage their use in this manner, suggesting "specificity, greater malleability, less inhibition, a more genuine 'been there, done that' (even if merely psychological) finality, an opportunity for a more thorough control of intervening variables" (Baldacchino, 2006, p. 6).

Indeed, as Baldacchino further argued, the apparent radicalism of 'the study of islands on their own terms' may both mask the extent to which islanders' terms are negotiated with those of the mainland and the extent to which island researchers are themselves entangled in complex webs of island dreams:

One must therefore be vigilant as to how nissologists / 'island scholars' may be reinterpreting 'terms' for islands, but maintaining the same deep structure and its colonizing disposition: while side-lining the narrative away from the perspective of the 'explorer-discoverer-colonist', it may be taken over by the perspective of the 'custodiansteward-environmentalist'. In this shift, the island narrative is still not enough a narrative by, for or with, islanders but remains one of and about them. (Baldacchino, 2008, pp. 49)

From the very start, island studies and Island Studies Journal have taken critical approaches to their scholarly project, encouraged by the theoretical freedom arising from interdisciplinarity. Indeed, for a field so frequently claimed to be undertheorised or potentially incapable of coherent theorisation (Hay, 2006; 2013), island studies has produced a considerable quantity of insightful and incisive theory. The problem-in so far as it is a problem-is that the diversity of disciplinary perspectives ensures no one is ever completely satisfied. From a literary studies perspective, Lisa Fletcher (2011, p. 8) has good reason to argue that "“island studies' scholarship is undermined by an untheorised distinction between 'geography' and 'literature"' and is right to criticise attempts to wrest apart physical and metaphorical islands. After all, the lives of islanders are inextricably bound up in island metaphors, symbols, and representations crafted in negotiation with the outside world, albeit in a negotiation often featuring imbalanced power relationships. Surely, regardless of whether one approaches island studies as a matter of 'place phenomenology' (Hay, 2006) or 'performative geographies' (Fletcher, 2011), one is left with the 'real', particular island that comes to stand in for the 'metaphorical', universal island-and vice versa. This is the underlying tension between "openness and closure" (Baldacchino, 2004, p. 274), between "islands as locus and focus" (Ronström, 2013). Writing of island cities, Hong Gang (2017) warns against privileging either the 'real' or the 'metaphorical' island, against making locus the enemy of focus:

In the absence of a holistic and dynamic understanding of the spatiotemporal, sociogeographic coproduction of an island city as both focus and locus, we risk what I wish to call island aphasia, symptomized in a series of fixations on mainland, particular islands, particular interpretations of the island/mainland dialectic, particular functions purported for islands, or particular social groups' imaginaries and deployment of islands.

What emerges from such theoretical introspection is the impression that the plurality of 'island studies' is not merely incidental; we are dealing less with a discipline than with multiple approaches to a single field. Baldacchino (2006, p. 9) presciently advocated for this when launching $I S J$, and it remains that case that most of us who are engaged in island studies are also engaged in other fields and retain connections to one or more home disciplines. We may lament and seek to remedy a lack of communication between the various strands of island studies, but it is a strength, not a weakness, of island studies that it encompasses diverse and possibly 
irreconcilable approaches, which interact with and inspire change in one another. As hinted at in the editorial introduction to the inaugural issue of the Shima journal of island cultural studies (Shima Editorial Board, 2007, p. 1), the existence of dedicated journals of island studies has helped protect the field against narrowing down into rigid disciplinary confines. Leading members of the island studies community would do well to guard against the (understandable) temptation to seek a coherent theoretical basis for the field or seek to establish particular thinkers from their respective disciplines as not merely useful but essential starting points for island studies thinking.

Philip Hayward (2016b, p. 5), a major island studies theorist and editor of Shima, recently called for "an expanded concept of island studies": If island studies is to "retain relevance as a field not only addressed to itself and its own institutions and orthodoxies (and thereby suspended in something of a narcissistic state) but also of relevance to other disciplines, communities and broader debates; it needs to reappraise its rationale and its 'edges'." Hayward's warning is an important one, and Shima has indeed helped advance new conceptualisations of the appropriate subject matters and borders of island studies, particularly through development of the 'aquapelago' as a theoretical framework focusing on human-land-sea interaction (launched in Hayward, 2012a; with subsequent contributions from, for example, Hayward, 2012b; Fleury, 2013; Alexander, 2015; Dick, 2015; MacKinnon, 2016; Bremner, 2017). In recent years, I have ventured outside my own scholarly comfort zone of remote, cold-water islands to help establish a distinctive form of urban island studies, which has not only brought new disciplinary perspectives (architecture, urban studies, urban planning) to bear on traditional island studies questions but has also highlighted hitherto under-appreciated connections between islands and cities as well as called into question certain assumptions about the nature of islandness in general (e.g., Grydehøj, 2015; Steyn, 2015; Hayward, 2015; Casagrande, 2016; Grydehøj \& Kelman, 2016; Gang, 2017).

Innovation is occurring within island studies from different directions, yet far from stultifying, $I S J$ has itself fostered a tradition of critical thinking. Hayward's aquapelago concept has featured in ISJ (most prominently, Fleury \& Johnson, 2015; Hayward, 2016a) and arose as a reaction to work within ISJ on the concept of the archipelago (Stratford et al., 2011; with subsequent contributions from, for example, Pugh, 2013a; Baldacchino \& Ferreira, 2013; Brinklow, 2013; Hidalgo et al., 2015). Jonathan Pugh (2016b) has continued this engagement with the archipelago outside the pages of ISJ, pursuing a powerful relational perspective. Even urban island studies began as a special thematic section of ISJ (e.g., Grydehøj, 2014a; 2014b; Picornell, 2014; Pons et al., 2014; Pigou-Dennis \& Grydehøj, 2014; Swaminathan, 2014). The concept of 'ecotones', or transitional spaces between ecological systems, has likewise recently been discussed in ISJ (Gillis, 2014; Petzold, 2018), pointing perhaps toward ways in which island studies could connect in the future with more natural sciences-oriented approaches, such as that of island biogeography. It is also worth noting that, whereas the wider literature on islands per se has tended to focus on Small Island Developing States (SIDS), sometimes at the risk of reifying the association between islandness and vulnerability, the island studies community has broadened the conversation and enriched comparative potentials by attending to both sovereign and nonsovereign islands at all stages of 'development'.

These and other theoretical innovations-developed within ISJ, Shima, Urban Island Studies, and elsewhere-have contributed to a richer island studies. Paradoxically, the focus on theorisation has made the field more outward-looking. Whereas the first decades of island studies' development saw the importation of discipline-specific and mutually incompatible (perhaps even mutually incomprehensible) theories into the field, the past decade has seen enhanced willingness to embrace diversity and apply explicitly island studies theories to problems outside island studies' traditional remit. As a result, it is increasingly difficult to label island studies a 'parochial pursuit'. 
Problems, however, remain. Some geographical regions remain largely untouched by island studies scholarship, despite considerable research into islands within these regions: for instance, South Asia, Southeast Asia, Russia, near-shore islands of Africa as a whole, and until recently South America and China (see Stratford, 2015). In addition, just as there are disciplinary divides within island studies, there exist various roughly parallel but partially non-communicative island studies traditions associated with particular languages of research (minimal exchange between, for example, the large English, French, and Japanese language island studies communities).

The reasons for the field's failure to gain purchase within various relevant strands of research and to communicate across internal divides are complex, but it is important not to lay blame on scholars outside the field or outside one's own particular segment of the field. Instead, island studies itself must own up to these shortcomings and-as part of the process of overcoming the discourse of 'emergence' — work to understand how the situation can be improved.

\section{The importance of expanding the reach of island studies}

But why, one might ask, is it really so important to expand the reach of island studies? What is wrong with maintaining our jovial, little, loosely assembled scholarly communities?

The problem goes to the root of island studies' purpose. There may be nothing wrong with merely considering islands on their own terms. It may be perfectly fine to exclude wider archipelagic, regional, and global dynamics in the process and to thereby present "islands as selfcentred" on account of our failure "to place island communities at the centre" (Grydehøj et al., 2015 , p. 4). But such insularity within island studies-such focus on what we already know, on continually reiterating that small islands are exceptional because they are small and that they are small (and capable of being regarded as independent units of analysis) because they are exceptional-risks missing the forest for the trees, the archipelago for the islands.

It is self-evidently problematic to study a particular island on what we believe to be its own terms and then to apply these-in an epic feat of deduction - to the wider state of 'islandness', without reference to the terms of other islands or to the geographical and symbolic units that interact with them. Yet most of us in island studies have, at one time or other, been complacent with overly broad deductive practices, as highlighted by Hay (2006). Such problematic deduction is inevitable when we deem satisfactory a woefully incomplete sample of the 'Islands of the World' (to borrow the title of the biennial ISISA conferences). How can we claim to understand the islands of the world when we ignore the immense archipelago of Southeast Asia? How are we to describe what makes islands 'special' when we only consider certain types of islands in certain parts of the world?

This is one argument in favour of pursuing urban island studies (Grydehøj, 2014b, p. 187), a subfield that has cast serious doubt upon important aspects of the scholarly discourse within the wider island studies, most significantly regarding the purported propensity for islands with small land areas to be economically marginalised, have small populations, and be remote from centres of power. If the wider island studies community is to benefit from urban island studies insights, it is necessary for the field to develop an understanding of 'island cities' and 'remote' or 'peripheral' islands as equally within the scope of island studies. Just as it would be absurd for researchers focused on Manhattan or Singapore to over-generalise and state that 'islands typically host major cities and serve as global hubs', it makes no sense for researchers focused on Saint Helena or Nauru to over-generalise and state that 'islands are typically peripheral from centres of political and economic power'. Royle (2002, p. 1) is, I believe, correct in stating that "islands everywhere are subject to the impact of a 
common range of constraints imposed because of their insularity." But if we are to successfully argue this point, it is necessary to truly consider 'islands everywhere'.

When efforts are made to insert new kinds of knowledge into island studies, contributions are likewise made by island studies to fields, disciplines, and regions within which island studies has made little previous impact. It is understandable that a small and institutionally fragile field such as island studies should foster a sense of internal protectiveness, of guarding the gates as it were, against incursions by other scholarly traditions. Island studies must gain depth, must continue devoting attention to introspection, yet it must also gain breadth and continue its productive interactions with a wide range of fields and disciplines.

\section{Darker sides of islands and island studies}

There are and will always be a truly limitless number of areas in which island studies could improve and ways in which it could grow. This is true for every field. However, I would like to take the opportunity to highlight two broad issues that I feel require particular attention inasmuch as they relate directly to island studies' underlying structures and history. The island studies community as a whole takes pride in its activist orientation, in its aim of improving the lives of islanders and safeguarding island cultures and environments. It is precisely because of this that we must take care that our activism points in the right directions and serves the right interests.

\section{Island studies and coloniality}

Baldacchino's concern that island studies may in some cases be reproducing a "hegemonic discourse of conquest" (Baldacchino, 2008, p. 49) has not been given the attention it deserves. Fletcher (2011) has noted the manner in which geography-oriented island studies has largely failed to get to grips with coloniality and postcoloniality. Clark (2013) has warned against the dangers of pursuing policy-making homogeneity undergirded by capitalist finance. Pugh (2013b, 2016a) has incisively questioned the neocolonial logics of island development research and policy-making. Androus and Greymorning (2016, p. 448) have emphatically argued that island studies has failed "to distinguish between Indigenous and other populations in surveying the benefits of affiliation over independence." Prinsen and Blaise (2017) have sought to conceptualise the emergence of a specifically 'islandic' form of Indigenous sovereignty. These critical voices have not, however, necessarily found purchase in the mainstream of policy-oriented and development-oriented island studies scholarship, which continues engaging in prescriptive approaches and wilful or wishful historical amnesia.

Island studies frequently focuses on former colonies and/or islands that remain in colonial or neocolonial relationships with metropolitan powers. Matters are complicated by the fact that it is often scholars from the metropole in question who are most active in undertaking research on these islands. The desire to 'study islands on their own terms' risks allowing scholars to overlook the effects of colonialism and to pursue scholarship that is bound up in the 'colonial matrix of power' without reflecting upon the "geo-politics of knowledge" (Mignolo, 2011, p. 138). This observation is not to deny metropolitan or mainland scholars a role in studying colonised or Indigenous communities, but it is necessary for such scholarship within island studies to take a more critical stance with regard to this role. Furthermore, the 'belittlement' of explicitly Indigenous and island research as such, about which scholars such as Hau'ofa (1994) and Gegeo (2001) wrote with such power, remains an obstacle for allowing islanders themselves to set the agenda-which may not be the same thing as 'setting the agenda on islands' own terms'. 
A first step is to reconsider one's position in the communities one researches, ruminating perhaps on what Nadarajah (2007, p. 129) calls an "in-betweenness of research engagement," involving "not simply the navigation and renegotiation of the ideologies of power, but rather a profound reflexive encounter with the ontological and epistemological coordinates of the socialtheoretical discourses that have underpinned the disciplinary terrain and practice." More fundamentally, it is important to understand the manner in which Western science tends to take its point of departure in Western questions, produce Western answers, and supply data to the Western scientific community (Mignolo, 2011; Pugh, 2013b; Smith, 2012). The solution to a lack of Indigenous or local island scholarship cannot lie merely in 'developing' island research and researchers until they reproduce Western research. Calling for a 'decolonial island studies', Nadarajah and Grydehøj (2016, pp. 441-443) suggest that:

much work remains to be done to disentangle the difference between colonization and coloniality and to determine how (and where) colonized peoples might find themselves in a decolonized world. [...] What some may regard as island empowerment, others may regard as the reaffirmation of colonial expectations and reinsertion of colonial influence. Strategies to 'sell' sovereignty (Overton \& Murray, 2014), exploit gaps in the jurisdictional market (Baldacchino, 2010), or receive payment for 'strategic services' (Grydehøj, 2016) may in fact serve as unintentional cover for a different kind of recolonization, especially on islands with vast extractive resources.

Beyond an understandable lack of desire on behalf of metropolitan scholars to personally take responsibility for the impacts of the colonial processes that have enriched and empowered their own societies, part of the reason for island studies' success in skirting around difficult issues of coloniality may lie precisely in the aforementioned 'island allure', in the idealisation of islands as communities unto themselves. The fact that much of the scholarship has thus far sought a return to 'islands on their own terms' as a means of combatting hegemonic mainland discourses has permitted researchers to sometimes push problems of coloniality out of the frame of reference.

\section{Island studies and sustainability}

A similar dynamic is behind the misuse-in policymaking, popular representation, and scholarship - of the conceptual simplicity of 'the island' for the purposes of presenting idealised visions of islandness. The straightforward mental bordering and distancing of islands can encourage the artificial isolation of island spaces and societies in a manner that presents islands in a better light than they perhaps deserve. This bordering process is particularly evident in the case of research into and pursuit of island sustainability. 'Sustainability' and 'sustainable development' are themselves contested concepts (Imran et al., 2014; Williams \& Millington, 2004), but they have gained currency in island studies and in numerous other fields of research and policy.

Baldacchino and Kelman (2014) have highlighted how the special role that islands play in the global discourse of sustainability has allowed certain Small Island Developing States to avoid grappling with possibly more serious or urgent policy concerns. Many low-lying coastal regions are at risk of inundation due to climate change, but the exceptional visibility and conceivability of islands comprehensively 'sinking' or 'disappearing' on account of sea-level rise can subject them to an "eco-colonial gaze" (Farbotko, 2010): Public, scholarly, and diplomatic concern for islands may focus on their representation as symbolic microcosms rather than on the actual needs of islanders. Grydehøj and Kelman $(2016,2017)$ argue that island spatiality encourages superficial 
and symbolic efforts at promoting sustainability and creating 'eco-islands', which produces numerous negative impacts on islands themselves and on efforts to engage in meaningful sustainability initiatives at a global scale-all the while serving powerful global corporate and political interests. Meanwhile, others have drawn attention to the manner in which islandness can conceal problematic governance and political practices (e.g., Veenendaal, 2015; Sheng, 2016; Baldacchino, 2012) as well as the 'offshoring' of controversial, reprehensible, risky, or simply unpopular activities to island territories (e.g., Mountz, 2011; Davis, 2007; Urry, 2014).

Island studies researchers have indeed led the way in highlighting this dark side to islandness, but more could be done to ensure that our work to overcome island marginalisation does not end up encouraging or lending legitimacy to harmful island practices. Whatever our passion for, or interest in, islands and islanders, it is important to nurture a healthy scepticism of real or perceived benefits of islandness as such. Our shared desire to promote the sustainability of island units and the wellbeing of island citizens must not blind us to the various accidental, unconscious, or intentional abuses and misuses of island status, by both islanders and external actors.

\section{Emergence}

I sit writing these words in my office at Ilisimatusarfik in Nuuk, the capital of Greenland. I can look out the window and watch the construction of a new university building, a centre for learning and island advocacy, rising up from the snow and stone. Out across the fjord, Sermitsiaq, the mountain of 'Eternal Ice', shines blue-white-more than a landmark, a beacon for the city.

\section{Figure 2: Sermitsiaq, seen from Nuuk, Greenland.}

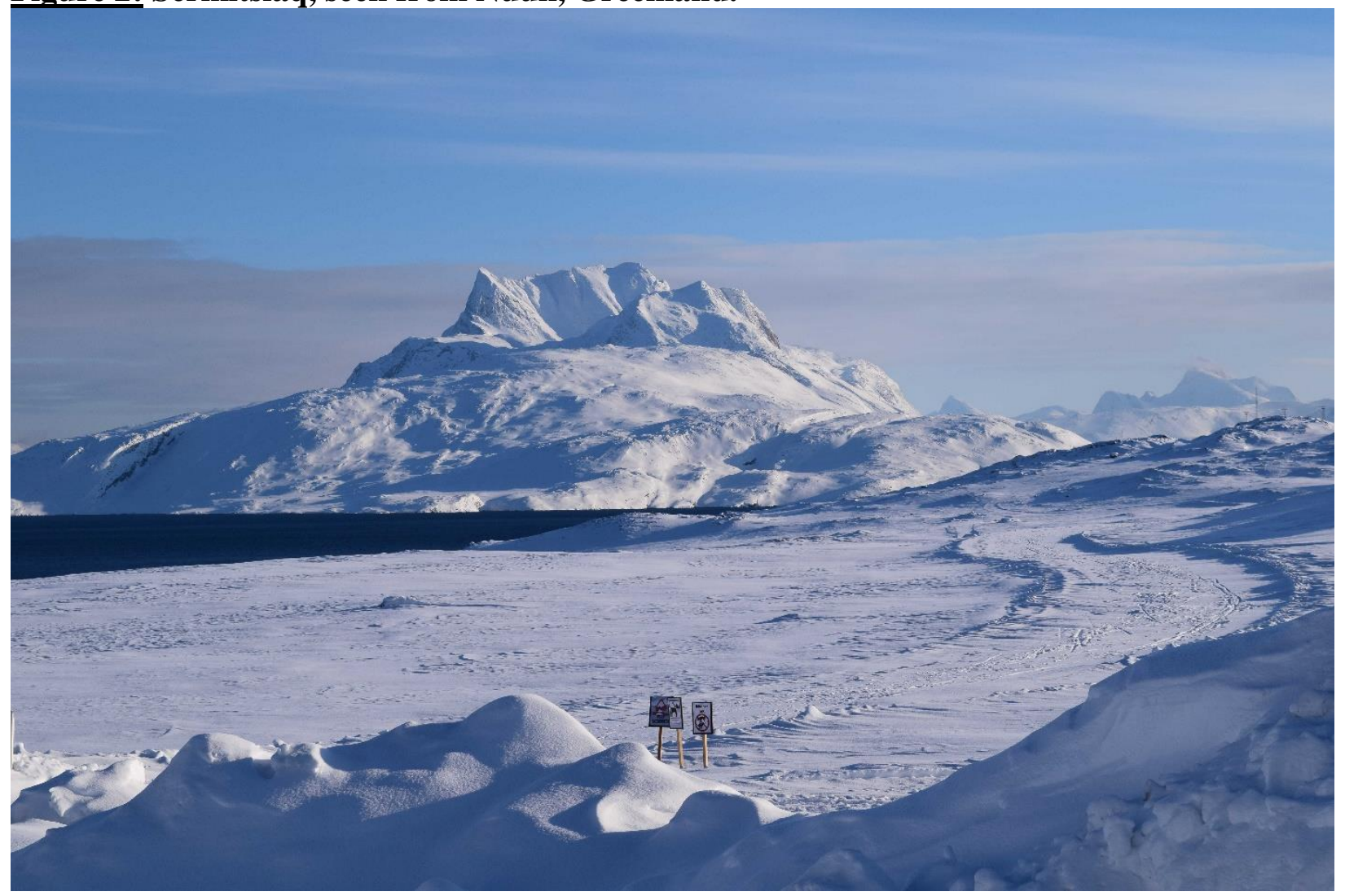

Source: Adam Grydehøj, 2017. 
This island, the largest in the world, is changing. Hunting, fishing, and other traditional Greenlandic livelihoods are rapidly becoming impossible to carry out-though not as rapidly as they are becoming unpopular among the younger generations. Greenland has been urbanising for the past century, but over the past two decades, the urbanisation trend has largely bypassed the island's many smaller towns and instead concentrated on Nuuk, the population of which has grown from just under 5,000 in 1967 to just under 17,000 today. The municipal government expects this figure to grow to 30,000 by 2030, amounting to over half of all Greenland's residents. Just nine years ago, Greenland got its first high-rises, and five years ago, it got its first escalators, inside its first shopping centre. Meanwhile, this autonomous territory of Denmark, weighed down by a fraught and complex colonial relationship, continues propelling itself, against all odds, toward political independence (Grydehøj, 2016).

As Arctic temperatures rise, Greenland's inland ice sheet (containing 10\% of the world's fresh water) is melting, posing risks for low-lying islands in the South Pacific, two oceans and half a world away. Yet as this ice melts, the land that it is depressing will be released of its burden, and Greenland itself will eventually rise up within the sea that encompasses it. New terrain, new resources, new challenges, new opportunities, new conflicts will emerge from the depths.

I cannot say there is any one compelling vision for Greenland's future.

But there is vision.

There are so many visions, so many possible futures, pursued with vigour or reluctance, emboldened by wisdom or folly, looking back or looking forward, that it would take a more confident prognosticator than I to foretell them. What is progress, and what is regression? What is development, and what is decline? Whose voice do you hear when you listen?

Over 20 years ago, Hau'ofa (1994, p. 151) spoke of his 'Road to Damascus' while traversing Hawai'i:

I saw such scenes of grandeur as I had not seen before: the eerie blackness of regions covered by recent volcanic eruptions; the remote majesty of Maunaloa, long and smooth, the world's largest volcano; the awesome craters of Kilauea threatening to erupt at any moment; and the lava flow on the coast not far away. Under the aegis of Pele, and before my very eyes, the Big Island was growing, rising from the depths of a mighty sea. The world of Oceania is not small; it is huge and growing bigger every day.

I cannot tell the future, but I have hope. We-the island studies community-are part of it, this future. Island Studies Journal is part of it. We must speak words of knowledge, contribute understanding, to islanders and to mainlanders, and to those who find themselves in between. And we must listen. Ours is an eclectic field, and though each of us point our separate ways, all these ways point toward the future.

There is not much I can tell you.

But if there is one thing I can tell you, it is this: Island studies has emerged. 


\section{Acknowledgments}

I wish to thank Godfrey Baldacchino, Laurie Brinklow, Lisa Fletcher, Ilan Kelman, Maeve McCusker, Evangelia Papoutsaki, Jan Petzold, and Elaine Stratford for their feedback and recommendations on an early draft of this paper.

\section{References}

Alexander, R. (2015). Career decision making in island communities: applying the concept of the aquapelago to the Shetland and Orkney Islands. Shima, 9(1), 38-52.

Androus, Z., \& Greymorning, N. (2016). Critiquing the SNIJ hypothesis with Corsica and Hawai'i. Island Studies Journal, 11(2), 447-464.

Baldacchino, G. (2015). The tenth volume of Island Studies Journal; and a tribute to one who helped make it happen. Island Studies Journal, 10(1), 3-7.

Baldacchino, G. (2012). Islands and despots. Commonwealth \& Comparative Politics, 50(1), 103120. https://doi.org/10.1080/14662043.2012.642119

Baldacchino, G. (2010a). Island brands and 'the Island' as a brand: insights from immigrant entrepreneurs on Prince Edward Island. International Journal of Entrepreneurship and Small Business, 9(4), 378-393. https://doi.org/10.1504/IJESB.2010.032400

Baldacchino, G. (2010b). Island enclaves: offshoring strategies, creative governance, and subnational island jurisdictions. Montreal: McGill-Queen's Press.

Baldacchino, G. (2008). Studying islands: on whose terms? Some epistemological and methodological challenges to the pursuit of island studies. Island Studies Journal, 3(1), 37-56.

Baldacchino, G. (2006). Islands, island studies, island studies journal. Island Studies Journal, 1(1), 3-18.

Baldacchino, G. (2004). The coming of age of island studies. Tijdschrift voor economische en sociale geografie, 95(3), 272-283. https://doi.org/10.1111/j.1467-9663.2004.00307.x

Baldacchino, G. (2002). A Taste of Small Island Success: A Case from Prince Edward Island. Journal of Small Business Management, 40(3), 254-259. https://doi.org/10.1111/1540$\underline{627 X .00055}$

Baldacchino, G. (1999). An exceptional success. Journal of Pacific Studies, 23(1), 27-47.

Baldacchino, G., \& Ferreira, E.C.D. (2013). Competing notions of diversity in archipelago tourism: transport logistics, official rhetoric and inter-island rivalry in the Azores. Island Studies Journal, 8(1), 84-104.

Baldacchino, G., \& Kelman, I. (2014). Critiquing the pursuit of island sustainability: Blue and Green, with hardly a colour in between. Shima, 8(2), 1-21.

Baldacchino, G., \& Milne, D. (Eds.) (2009). The case for non-sovereignty: lessons from subnational island jurisdictions. London \& New York: Routledge.

Baldacchino, G., \& Milne, D.A. (2000). Lessons from the political economy of small islands. Houndsmills: Macmillan \& St Martin's. https://doi.org/10.1007/978-1-349-62865-0

Bremner, L. (2017). Observations on the concept of the aquapelago occasioned by researching the Maldives. Shima, 11(1), 18-29. https://doi.org/10.21463/shima.11.1.05

Brinklow, L. (2013). Stepping-stones to the edge: artistic expressions of islandness in an ocean of islands. Island Studies Journal, 8(1), 39-54.

Brinklow, L. (2011). The proliferation of island studies. Griffith Review, 34, 167. 
Casagrande, M. (2016). Heritage, tourism, and demography in the island city of Venice: depopulation and heritagisation. Urban Island Studies, 2, 121-141. https://doi.org/10.20958/uis.2016.6

Clark, E. (2013). Financialization, sustainability and the right to the island: a critique of acronym models of island development. Journal of Marine and Island Cultures, 2(2), 128-136. https://doi.org/10.1016/j.imic.2013.10.001

Davis, J.S. (2007). Scales of Eden: conservation and pristine devastation on Bikini Atoll. Environment and Planning D: Society and Space, 25(2), 213-235. https://doi.org/10.1068/d1405

Dick, T. (2015). Chorographing the Vanuatu aquapelago: engaging with performatively constituted specificities of place. Shima, 9(1), 1-22.

Farbotko, C. (2010). Wishful sinking: disappearing islands, climate refugees and cosmopolitan experimentation. Asia Pacific Viewpoint, 51(1), 47-60. https://doi.org/10.1111/j.14678373.2010.001413.x

Fletcher, L. (2011). '... some distance to go': a critical survey of Island Studies. New Literatures Review, 47-48, 17-34.

Fleury, C. (2013). The island/sea/territory: towards a broader and three dimensional view of the aquapelagic assemblage. Shima, 7(1), 1-13.

Fleury, C., \& Johnson, H. (2015). The Minquiers and Écréhous in spatial context: contemporary issues and cross perspectives on border islands, reefs and rocks. Island Studies Journal, 10(2), 163-180.

Gang, H. (2017). Locating Zhuhai between land and sea: a relational production of Zhuhai, China as an island city. Island Studies Journal 12(2), forthcoming. https://doi.org/10.24043/isj.16

Gegeo, D.W. (2001). Cultural rupture and indigeneity: the challenge of (re)visioning 'place' in the Pacific. The Contemporary Pacific, 13(2), 491-507. https://doi.org/10.1353/cp.2001.0052

Gillis, J.R. (2014). Not continents in miniature: islands as ecotones. Island Studies Journal, 9(1), $155-166$.

Grydehøj, A. (2016). Navigating the binaries of island independence and dependence in Greenland: Decolonisation, political culture, and strategic services. Political Geography, 55, 102-112. https://doi.org/10.1016/j.polgeo.2016.09.001

Grydehøj, A. (2015). Island city formation and urban island studies. Area, 47(4), 429-435. https://doi.org/10.1111/area.12207

Grydehøj, A. (2014a). Constructing a centre on the periphery: urbanization and urban design in the island city of Nuuk, Greenland. Island Studies Journal, 9(2), 205-222.

Grydehøj, A. (2014b). Guest editorial introduction: understanding island cities. Island Studies Journal, 9(2), 183-190.

Grydehøj, A., \& Kelman, I. (2017). The eco-island trap: climate change mitigation and conspicuous sustainability. Area, 49(1), 106-113. https://doi.org/10.1111/area.12300

Grydehøj, A., \& Kelman, I. (2016). Island smart eco-cities: innovation, secessionary enclaves, and the selling of sustainability. Urban Island Studies, 2, 1-24. https://doi.org/10.20958/uis.2016.1

Grydehøj, A., Pinya, X.B., Cooke, G., Doratlı, N., Elewa, A., Kelman, I., Pugh, J., Schick, L., \& Swaminathan, R. (2015). Returning from the horizon: introducing Urban Island Studies. Urban Island Studies, 1, 1-19. https://doi.org/10.20958/uis.2015.1

Hau'ofa, E. (1994). Our sea of islands. The Contemporary Pacific, 6(1), 147-161. 
Hay, P. (2013). What the sea portends: a reconsideration of contested island tropes. Island Studies Journal, 8(2), 209-232.

Hay, P. (2006). A phenomenology of islands. Island Studies Journal, 1(1), 19-42.

Hayward, P. (2016a). Enduring perceptions: Placenaming and the perception of Louisiana's salt dome islands. Island Studies Journal, 11(2), 417-430.

Hayward, P. (2016b). Introduction: towards an expanded concept of island studies. Shima, 10(1), 1-7. https://doi.org/10.21463/shima.10.1.03

Hayward, P. (2015). The aquapelago and the estuarine city: reflections on Manhattan. Urban Island Studies, 1, 81-95. https://doi.org/10.20958/uis.2015.5

Hayward, P. (2012a). Aquapelagos and aquapelagic assemblages. Shima, 6(1), 1-11.

Hayward, P. (2012b). The constitution of assemblages and the aquapelagality of Haida Gwaii. Shima, 6, 1-14.

Hepburn, E., \& Baldacchino, G. (Eds.) (2016). Independence movements in subnational island jurisdictions. London: Routledge.

Hidalgo, C., Ther, F., Saavedra, G., \& Díaz, A. (2015). Affordance of landscapes and economic socio-spatial networks in the Quinchao archipelago, Chile: a contribution to landscape research and island studies. Island Studies Journal, 10(1), 49-70.

Imran, S., Alam, K., \& Beaumont, N. (2014). Reinterpreting the definition of sustainable development for a more ecocentric reorientation. Sustainable Development, 22(2), 134144. https://doi.org/10.1002/sd.537

King, R. (2015). Journal of Island Studies: preliminary ideas from 1991, and comments from 2015. Island Studies Journal, 10(1), 7-14.

MacKinnon, S.R. (2016). STARGATE ATLANTIS: Islandness in the Pegasus Galaxy. Shima, 10(2), 36-49. https://doi.org/10.21463/shima.10.2.06

McCall, G. (1994). Nissology: a proposal for consideration. Journal of the Pacific Society, 6364(17), 93-106.

Mignolo, W.D. (2011). The Darker Side of Western Modernity. Durham NC \& London: Duke University Press. https://doi.org/10.1215/9780822394501

Mountz, A. (2015). Political geography II: islands and archipelagos. Progress in Human Geography, 39(5), 636-646. https://doi.org/10.1177/0309132514560958

Mountz, A. (2011). The enforcement archipelago: detention, haunting, and asylum on islands. Political Geography, 30(3), 118-128. https://doi.org/10.1016/j.polgeo.2011.01.005

Nadarajah, Y. (2007). The outsider within: commencing fieldwork in the Kuala Lumpur/Petaling Jaya corridor, Malaysia. International Journal of Asia-Pacific Studies, 3(2), 109-132.

Nadarajah, Y., \& Grydehøj, A. (2016). Island studies as a decolonial project. Island Studies Journal, 11(2), 437-446.

Petzold, J. (2018). Social adaptability in ecotones: sea-level rise in Flushing and the Isles of Scilly, UK. Island Studies Journal, 12(1), forthcoming. https://doi.org/10.24043/isj.17

Picornell, M. (2014). Insular identity and urban contexts: representations of the local in the construction of an image of Palma (Mallorca, Balearic Islands). Island Studies Journal, 9(2), 223-238.

Pigou-Dennis, E., \& Grydehøj, A. (2014). Accidental and ideal island cities: islanding processes and urban design in Belize City and the urban archipelagos of Europe. Island Studies Journal, 9(2), 259-276.

Pons, A., Rullan, O., \& Murray, I. (2014). Tourism capitalism and island urbanization: tourist accommodation diffusion in the Balearics, 1936-2010. Island Studies Journal, 9(2), 239-258. 
Prinsen, G., \& Blaise, S. (2017). An emerging 'islandian' sovereignty of non-self-governing islands. International Journal, forthcoming. https://doi.org/10.1177/0020702017693260

Pugh, J. (2016a). Postcolonial development, (non)sovereignty and affect: living on in the wake of Caribbean political independence. Antipode, forthcoming. https://doi.org/10.1111/anti.12305

Pugh, J. (2016b). The relational turn in island geographies: bringing together island, sea and ship relations and the case of the Landship. Social \& Cultural Geography, 17(8), 1040-1059. https://doi.org/10.1080/14649365.2016.1147064

Pugh, J. (2013a). Island movements: thinking with the archipelago. Island Studies Journal, 8(1), 9-24.

Pugh, J. (2013b). Speaking without voice: participatory planning, acknowledgment, and latent subjectivity in Barbados. Annals of the Association of American Geographers, 103(5), 1266-1281. https://doi.org/10.1080/00045608.2012.706571

Rankin, J.R. (2016). Tracing archipelagic connections through mainland islands. New Zealand Geographer, 72(3), 205-215. https://doi.org/10.1111/nzg.12138

Ronström, O. (2013). Finding their place: islands as locus and focus. cultural geographies, 20(2), 153-165. https://doi.org/10.1177/1474474012445446

Royle, S.A. (2002). A Geography of Islands: Small Island Insularity. London \& New York: Routledge.

Sheng, L. (2016). The transformation of island city politics: the case of Macau. Island Studies Journal, 11(2), 521-536.

Shima Editorial Board (2007). An introduction to island culture studies. Shima, 1(1), 1-5.

Smith, L.T. (1999). Decolonizing methodologies: research and indigenous peoples. London \& New York: Zed Books.

Steyn, G. (2015). The impacts of islandness on the urbanism and architecture of Mombasa. Urban Island Studies, 1, 55-80. https://doi.org/10.20958/uis.2015.4

Stratford, E. (2015). A critical analysis of the impact of Island Studies Journal: a retrospect and prospect. Island Studies Journal, 10(2), 139-162.

Stratford, E., Baldacchino, G., McMahon, E., Farbotko, C., \& Harwood, A. (2011). Envisioning the archipelago. Island Studies Journal, 6(2), 113-130.

Swaminathan, R. (2015). Ports and digital ports: the narrative construction and social imaginaries of the island city of Mumbai. Urban Island Studies, 1, 35-54. https://doi.org/10.20958/uis.2015.3

Swaminathan, R. (2014). The epistemology of a sea view: mindscapes of space, power and value in Mumbai. Island Studies Journal, 9(2), 277-292.

Urry, J. (2014). Offshoring. London: Polity.

Veenendaal, W.P. (2015). Democracy in microstates: why smallness does not produce a $\begin{array}{lll}\text { democratic political system. } & \text { Democratization, } & \text { 22(1), }\end{array}$ https://doi.org/10.1080/13510347.2013.820710

Williams, C.C., \& Millington, A.C. (2004). The diverse and contested meanings of sustainable development. The Geographical Journal, 170(2), 99-104. https://doi.org/10.1111/j.0016$\underline{7398.2004 .00111 . x}$ 